\title{
PRICING IN THE RAILWAY TRANSPORT
}

\author{
Marta Jarocka $^{1}$, Urszula Ryciuk ${ }^{2}$
}

Faculty of Managment, Bialystok University of Technology, Bialystok, Poland

E-mails: ${ }^{1}$ m.jarocka@pb.edu.pl (corresponding author); ${ }^{2}$ u.ryciuk@pb.edu.pl

\begin{abstract}
The pricing policy seems to be very important part of the strategy of the entire enterprise. The company's position on a competitive market depends on the ability to make optimal pricing decisions. The article discusses the determinants of transport services' prices and methods of their calculation (cost method, demand method and method based on competition). The main objective of the paper is the identification of the pricing determinants in the context of the rail transport. According to the authors, the most important determinants of rail transport services prices are mainly connected to prime cost, but also to factors classified into following groups: transportation enterprise, customer, market and competition. The introduction to the research was the examination of the largest rail operators in Poland and their pricing models.
\end{abstract}

Keywords: pricing, transport, railway, pricing model, pricing policy, rail operators.

JEL Classification: D40; R41; M31.

\section{Introduction}

In the era of increasing global competition and a wide access to information, enterprises undertake different functional strategies. In order to achieve strategic objectives, along with financial or production strategy, marketing strategy, where one of the elements is the price, is extremely important. This is the only element of the mix marketing (the three others are: product, promotion and place) which does not generate costs and is easy to implement. Determining the optimal level and the structure of prices determines company's profit and consequently, its development and competitive position. However in the era of easy access to information and possibility of quick comparison of the prices on the market, it seems to be a challenge to define clients' needs, establish the value of the service, distinct the offer and sale services on the prices higher than competitors. Pricing policy shall also allow the enterprise to gain profits, undertake new investments and develop dynamically.

Pricing strategy, the optimal level and structure of services prices might contributes to creation of the brand image and trust level towards particular enterprise. Furthermore, price management is also extremely important in building durable relationships with customers. Adjusting price strategy to unique requirements and price preferences of individual clients as well as creation of the price rate depending on time and intensity of cooperation influence building relationships with clients based on loyalty and sense of attachment, and consequently on reaching competitive advantage on the market.

According to Nagle et al. (2011), pricing is a "tactical lever to close deals and achieve sales objectives" but is "not simply about calculating the "right" price for the product or service" but it requires "looking beneath the demand curve and to understand and manage the monetary and psychological value that is primary determinant of the purchase decision".

The main objective of the paper was the identification of the determinants of rail transport services' prices. The introduction to the research was the examination of the largest rail operators in Poland and their pricing models.

\section{Price management in transport services}

The price is the amount of money that customer has to pay for a product or service (Kotler 1999). The prices of transport services have the following macroeconomic and microeconomic functions (Koźlak 2007):

- informative - the client of the service is informed about the value of various transportation services by its price; information about the prices influence the structure and level of demand;

- stimulative - price is a tool which stimulates the service providers and consumers 
of transportation services, to undertaking particular actions;

- income determination - prices determine the level of enterprise's financial income;

- income redistribution - price is a tool dividing the goods and services as well as shifting the income from one social group to others or to the state budget;

- balancing supply and demand - prices can be means of restoring market balance.

Invariably, the challenge for all companies is the determination of the level of price that should be associated with the value of the service perceived by the buyers. In economic theory, there are three methods of calculating prices, that might also be applied to transport services (Koźlak 2007; Rokicki 2014):

- costs method - the price includes the unit costs incurred by the company to produce services and a price margin (the dominating method),

- demand method - the basis for determining the price is an existing or anticipated demand,

- method based on competition - price is determined on the basis of price analysis of competing services.

Consequently, Nagle et al. (2011) mention value-based (customer-driven) pricing strategy consistent with the necessity to take into consideration market conditions and consumer needs, costplus pricing based on unit cost estimation and share-driven pricing related to competitive conditions analysis. The authors propose the pricing piramide that means five levels of pricing strategy building depending on specifics of each product and market, namely:

1) Value creation,

2) Price structure,

3) Price and value communication,

4) Pricing policy,

5) Price level.

According to the Nagle et al. (2011) research, companies that developed and executed valuebased pricing strategies earn 31 percent higher income than companies whose pricing strategies are driven by market share goals or target margins. Literature (Hinterhuber 2008; Töytäri et al. 2015) defines value-based pricing as pricing based on the value that a product or service delivers to a customer (profitable and affecting the company's long-term success approach but very difficult to predict and implement).

According to Sokołowska and Schulz (Sokołowska, Schultz 2014) setting prices by means of only one of the above mentioned methods is not possible - those methods cannot be used independently but complementary since the success of the enterprise on the market depends on price defined on the basis of costs of providing services but with consideration of demand intensity and activities undertaken by competitors.

In the case of rail transport services, the choice of company's pricing strategy should be based not only on costs but also on the results of the analysis of factors such as demand, competition but also government policy in terms of setting prices.

According to the Global Pricing Study 2014 research, current market requirements caused the ability of enterprises to achieve high prices to decrease to the lowest, for 5 years, level which forces on the enterprises to search for new possibilities to generate profit. The preferable option seems to be introduction of innovative products and services but majority of enterprises do not reach the assumed profits, since they neglect key pricing and marketing issues. Low profits, on the other hand, absorb sources for the future development projects which influences the profitability of the company and in a broader perspective their existence on the market (Global Pricing Study 2014).

Researchers like Hinterhuber and Liozu (2014) criticise companies pricing strategies based only on competition- and/or cost-based pricing, and pricing tactics limited only to for example discounting. According to the authors, companies need innovative approach towards pricing, in contrast to treating pricing antagonistic, only as a winlose relationship with customers. Hinterhuber and Liozu (2014) propose a roadmap for introducing innovation in pricing in three main elements: strategy, tactics and organization and suggest that innovation in pricing is possible even without product innovation but product innovation without pricing innovation reduces the possibility for profitability increase.

Iveroth et al. (2013) developed model that suggests that company might differentiate by price along five dimensions, named: scope, base, influence, formula and temporal rights. In the authors opinion, pricing should be based on long-term strategic thinking and any agreement between seller and buyer should use one particular price model that can be described through five mentioned dimensions.

Respectively, Shipley and Jobber (2001) suggested the pricing wheel, which can be useful in the process of elaboration pricing policy of enterprises. The authors state that pricing decisions should be flexible, continuous and integrate "the full range of forces that impact pricing effective- 
ness". Pricing wheel is a concept of multistage process for price management. Generally, the elements of the pricing wheel are as follows: deciding the role of price in the company's marketing strategy, prioritizing pricing objectives, assessing all pricing determinants, deciding about price strategies, selecting pricing methods and implementation, evaluation and price control (Fig. 1).

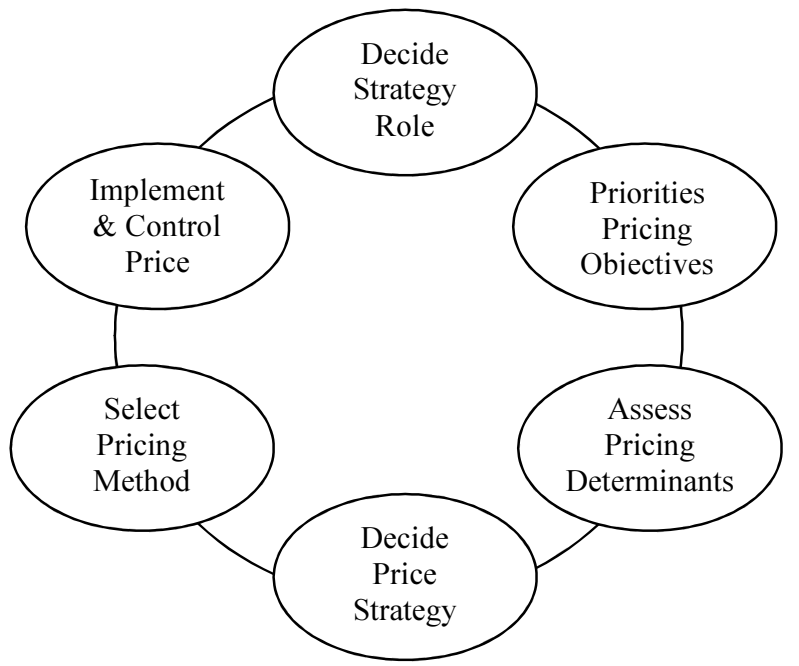

Fig. 1. The pricing wheel (Source: Shipley, Jobber 2001)

One of the critical elements of price wheel is assessing all determinants of price. In accordance to that, the authors, selected and described, in their opinion, the most significant pricing determinants in rail transport services. First, the price determinants of the largest rail operators in Poland were examined.

\section{Pricing model used by Polish rail operators}

Price management is an important element of the railway enterprise activities, especially when there are many competing companies operating on the market.

According the Office of Rail Transport in Poland there are 66 freight railway operators, licensed in Poland (Website of the Office of Rail Transport in Poland). In fact, the market is dominated by several large enterprises, of which the largest share of the market has PKP Cargo (Fig. 2).

There are contract and tariff prices used on the market of transport services. Contract prices are the result of customer negotiations with the company and are most often used in road transport and inland waterways. The tariff prices are based on the tariffs, which are provided to the public information in a form of a freight rates' table. They are used in such modes of transport as rail transport, via pipelines and sea transport.

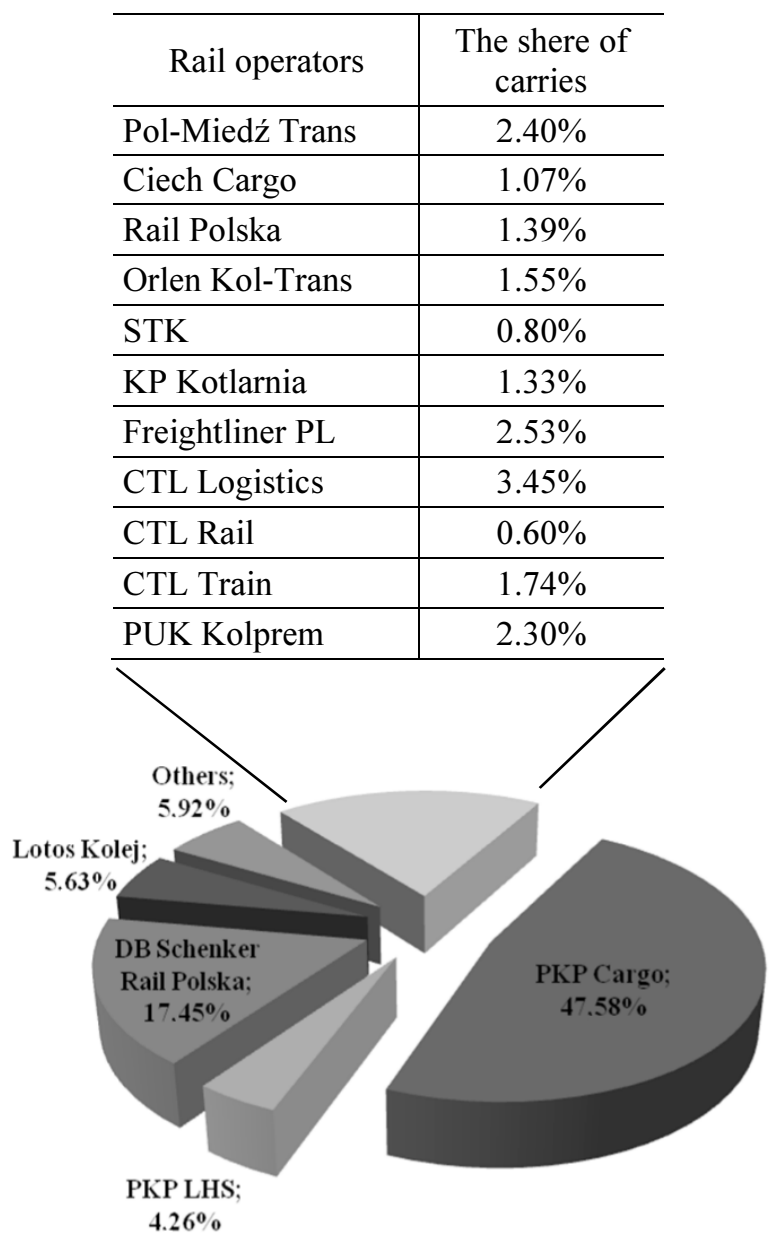

Fig. 2. The share of carriers according to weight of the goods transported, January - August 2015, the share

$>0.5 \%$ (Source: Website of the Office of Rail Transport in Poland)

Apart from the tariff prices, transport companies publish comprehensive information and the rules for the international shipment of goods. In Poland, prices of railway services depend mainly on the distance tariff and the weight of the consignment. Table 1 shows the list of price determinants of the largest rail operators in Poland.

In Poland, transportable calculation is based on the model of "cost plus". Price of the transport service is based on unit costs and price margins (Jaruga et al. 1999). It is the most common pricing procedure, because such model carried a sense of financial security. Undoubtedly the advantage of this method is its simplicity, the ability to document the agreed price and the fact that such prices reduce the risk of losing the profit (price guarantees to cover the costs and provides the necessary income). But its disadvantage is the fact that the price is based only on costs and ignores external relations for example it does not take into account the influence of consumers and competition. 
Table 1. The price determinants of the largest rail operators in Poland (Source: Freight tariff of CTL 2016; Terms and conditions 2016; Tariff of railway 2016; DB Schenker 2016)

\begin{tabular}{l|l}
\hline \multicolumn{1}{c|}{$\begin{array}{c}\text { Transport } \\
\text { company }\end{array}$} & \multicolumn{1}{c}{ Determinant's price } \\
\hline PKP Cargo & $\begin{array}{l}\text { type of product (product name) } \\
\text { tariff weight of the consignment } \\
\text { distance tariff } \\
\text { type of delivery } \\
\text { other conditions provided in the tar- } \\
\text { iff price calculated separately for } \\
\text { each carriage }\end{array}$ \\
\hline DB Schenker & $\begin{array}{l}\text { type of contracted shipments } \\
\text { weight } \\
\text { Rail Polska S.A. }\end{array}$ \\
\hline Lotos Kolej & $\begin{array}{l}\text { distance tariff } \\
\text { weight }\end{array}$ \\
\hline CTL Logistics & $\begin{array}{l}\text { type of products } \\
\text { weight of the consignment } \\
\text { distance tariff } \\
\text { type of the consignment } \\
\text { the property of the train or carriages } \\
\text { other conditions set out in the tariff }\end{array}$ \\
\hline CTL Rail &
\end{tabular}

The current pricing systems of railway transport enterprises is simply a linear function of the size of the transshipment and the length of the train route. This model does not take into account qualitative factors, which among other things include the relationship with the customers. The main drawback in the costs method seems to be the possibility to lose assumed profits related to the consideration of clients' opinions and their willingness to use particular service at higher prices. Cost-plus model also does not take into consideration the prices offered by competing companies (Dyhdalewicz 2011). Moreover, the pricing system does not take into account current market needs.

\section{Determinants of transportation services prices}

In authors opinion the cost model of transport should be dynamic and open. The choice of company's pricing strategy should depend on its marketing strategy and should be based not only on costs but also on the results of the analysis of factors such as demand, competition and government policy in terms of setting prices. The model shall be designed on the basis of various factors and requirements.

In literature there are many factors which are identified as determining the costs of transportation
(Koźlak 2007; Iveroth et al. 2013; Waniowski 2014). On the market of transport services, enterprises' pricing strategy depends on many factors, from which the most important are: costs, market factors, state interventions and socio-economic factors (Koźlak 2007). Figure 3 presents one of examples of identified factors affecting costs of transportation services.

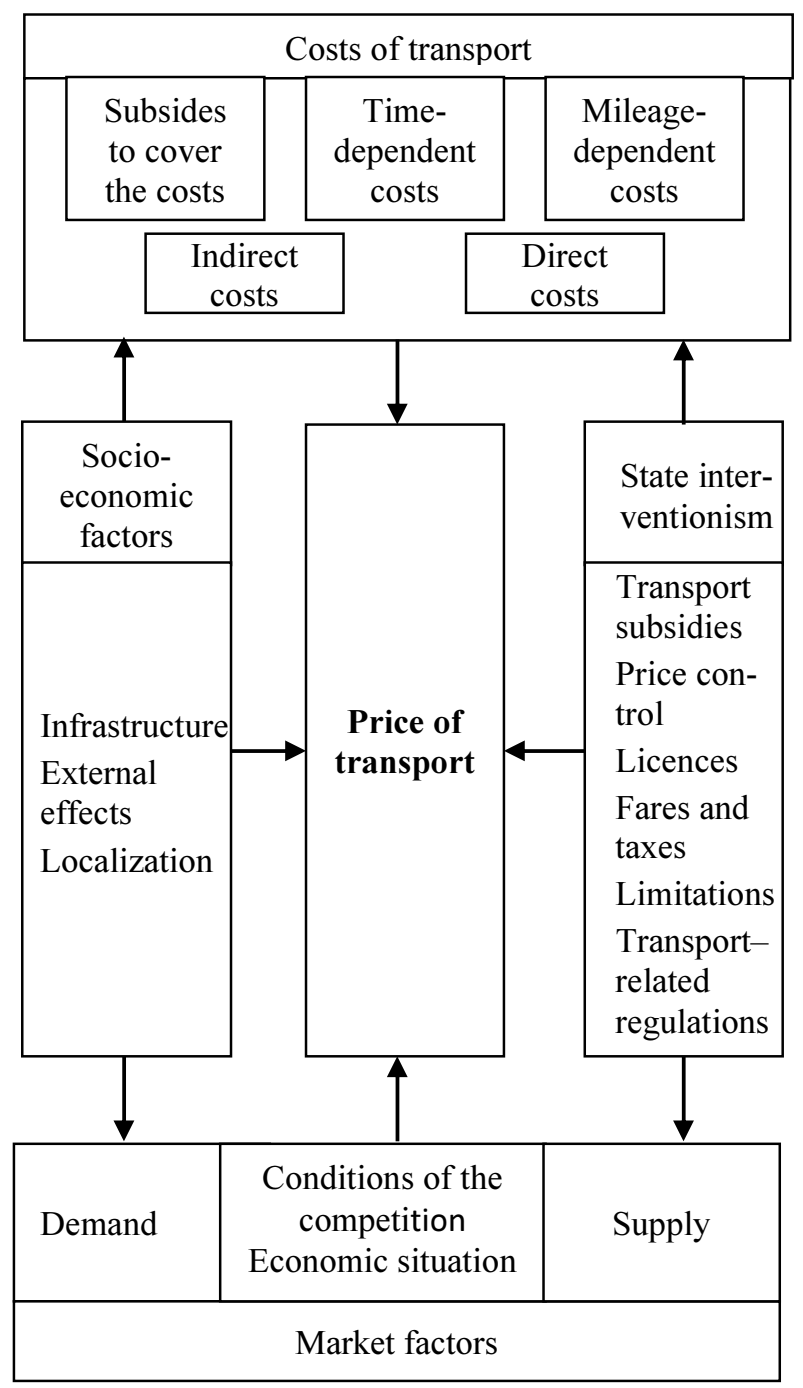

Fig. 3. The factors affecting costs of transportation (Source: Koźlak 2007)

Another concept of the set of factors influencing the service prices which may be related to the transportation prices, is the suggestion of Waniowski (2014), elaborated on the basis of Urbany (2000) Work.

The choice of basic price depends mainly on the assumptions made in the enterprise marketing and price strategies, demand, competition and law regulations (Fig. 4). 


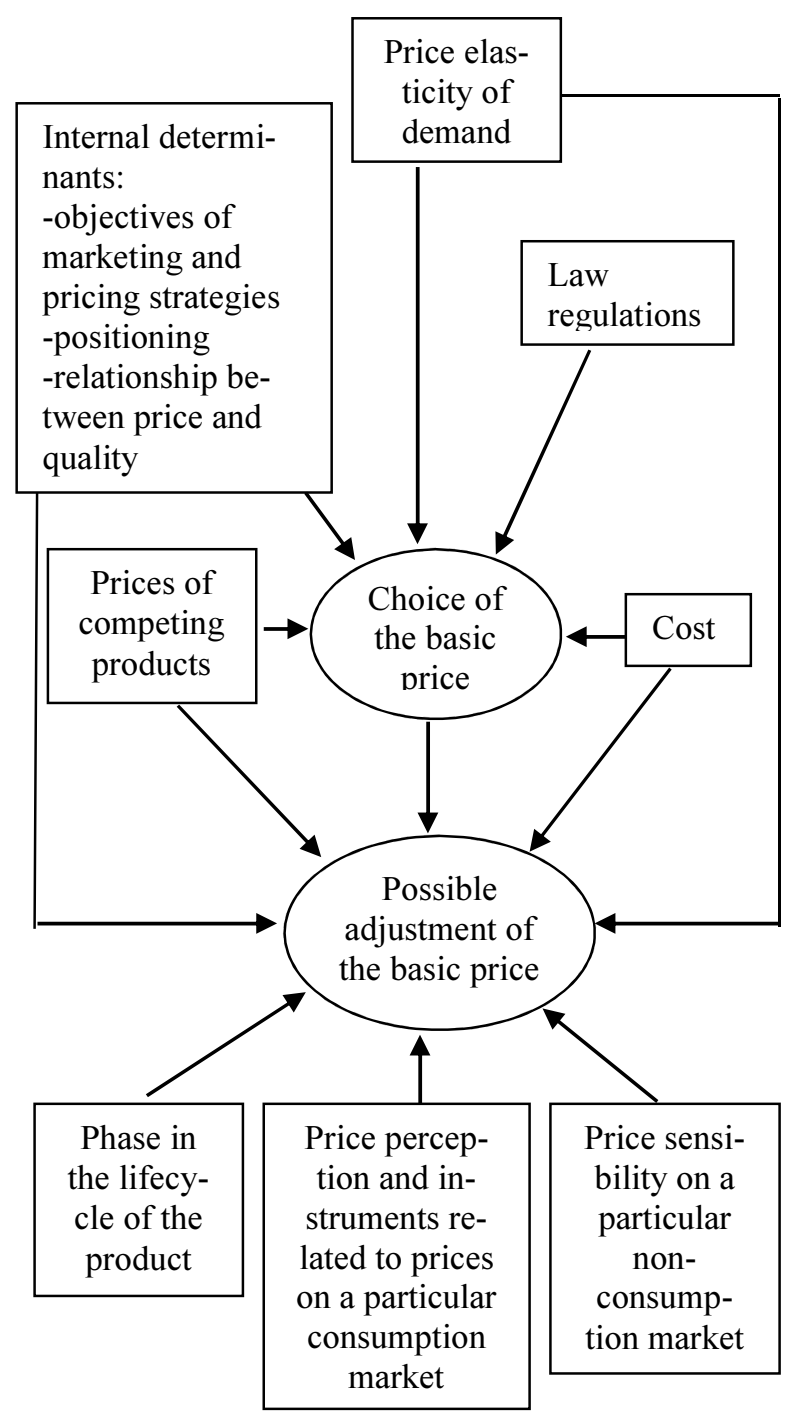

Fig. 4. The determinants of price (Source: Waniowski 2014)

The group of basic determinants is complemented by other factors such as: the phase in the lifecycle of the product, price perception and instruments related to prices on a particular consumption market as well as price sensibility on a particular non-consumption market.

Taking into consideration sets of price determinants presented above, the authors of the following discourse, made an attempt to introduce them in the context of the rail transport. The authors indicated and described their own determinants of services prices in railway transport (Fig. 5).

The most significant determinant of each transportation service seems to be the prime costs which predominantly reflects the costs of services production and human resources. In the generic embrace, these are costs of depreciation, materials and energy usage, salaries, insurance, taxes, fees, external services and the remaining costs. Basic categories of costs in transportation enterprises are: the costs of covering maintenance and exploitation of transport infrastructure, the cost of exploitation and maintenance of transport means (employment costs as well as transport infrastructure maintenance) (Bronk 2015).
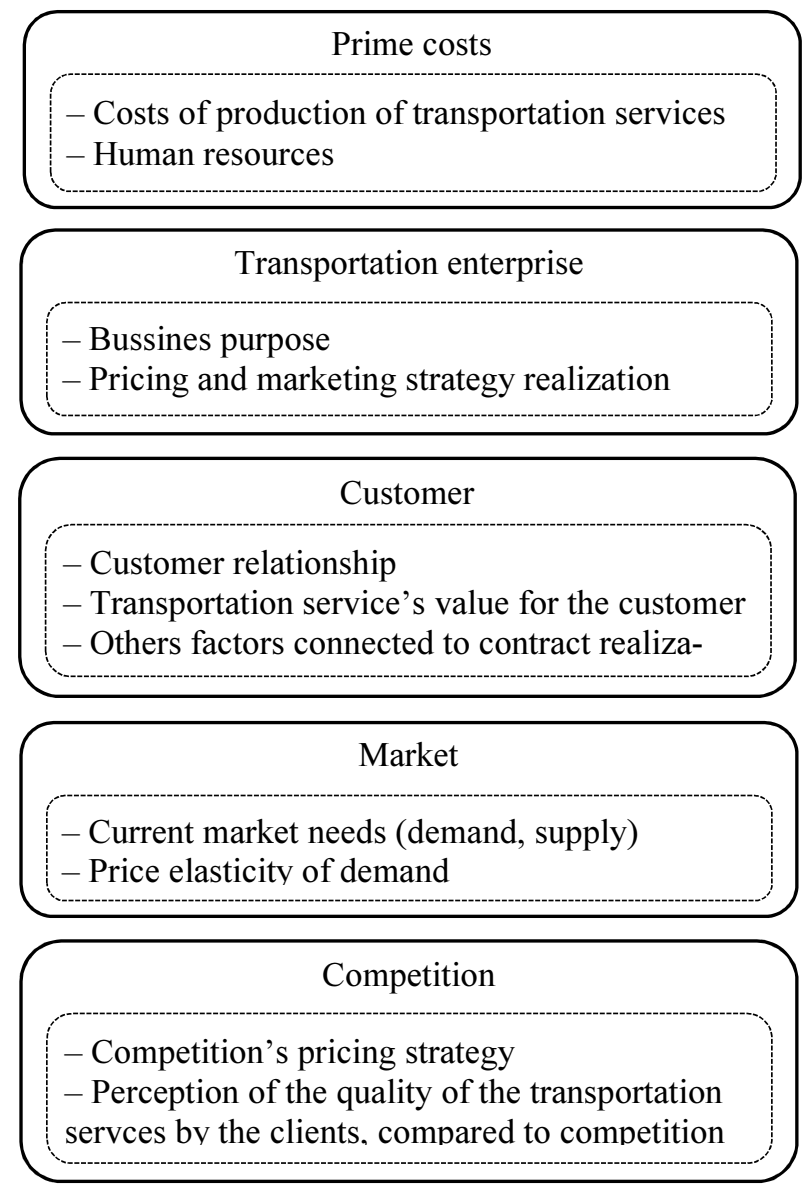

Fig. 5. The determinants of prices for railway transport (Source: made by authors)

The prime costs incurred for production of transportation service shall simultaneously indicate the minimal price of the transportation service which constitutes a starting point in the process of indicating the final price. Its final level shall oscillate in, so called, acceptable price range which is heavily reliant to various groups of factors, classified as follows:

- transportation enterprise,

- customer,

- market,

- competition.

The second group of factors influencing the transportation price constitute factors related to functioning of the transportation enterprise. The pricing strategy shall be dependent on, inter alia, business purpose of a company what may be reflected in the plan of profit increase from the service sales, market penetration, rate of return from a 
chosen group of clients or introduction of a new transport services on the market. Crucial seems to be price and marketing strategy. In order to generate maximum sales rate and simultaneously penetrate the market, the transportation business will decide to use the strategy of low prices. However, if the company aims to increase the rate of return and improvement of the position on the market, its managers will decide to implement the high prices strategy. Through the implementation of the neutral prices strategy, close to the average level on the market, the carries will be forced to compete on the market by means of other marketing mix tools (service, place, promotion). What is more, the exemplary solution would be to elaborate price strategy with precisely defined pricing model which would integrate three types of price policies:

- policy oriented on costs (income from sales of services shall cover total costs of conducted business activity and generate profit),

- policy oriented on competition (price shall be determined by the prices set by competitive companies),

- policy oriented on demand (price shall be adjusted to the market conditions in order to balance demand and supply).

Observing the price model, also the relationship with the client shall be taken into consideration. Price of transportation services shall be flexible, determined by the factors such as: customer loyalty/long-term cooperation, new client, client of key importance. Strategy of prices discrimination for cargo transportation shall also embrace:

- nature of transportation (compact or distributed),

- client localization,

- frequency of ordered services,

- number of ordered services,

- size of a single contract,

- due date,

- time of the transportation service realization,

- seasonality,

- speed of the transportation service realization.

In the process of forming prices of transportation services, the significant role falls to psychology of clients' behaviors. The enterprise willing to understand clients' behavior and their tendency to accept new price will be able to make proper decision related to price. Therefore, it seems to be important to establish the value of provided services perceived by the client and then skillfully use acquired information. As Antonowicz (2014) notices, identification and monitoring of consumer value constitute marketing innovation in the transportation field (Fig. 6).

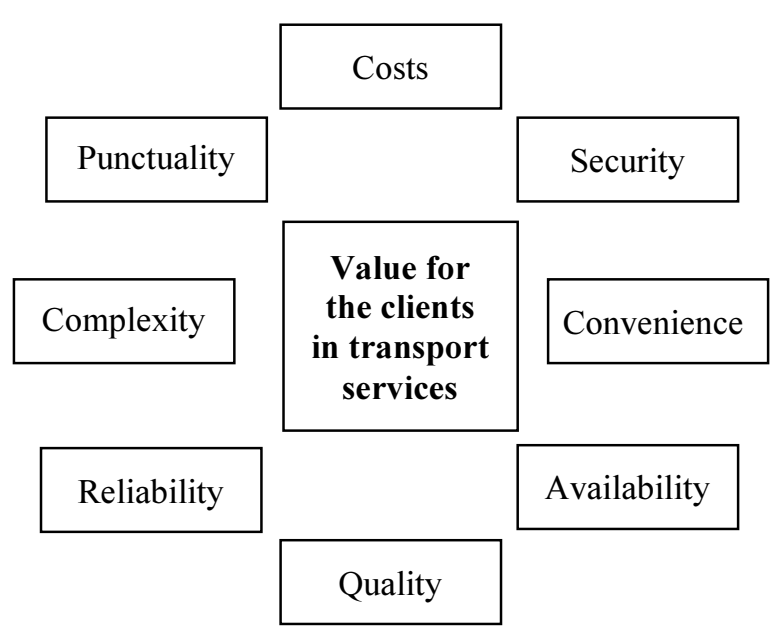

Fig. 6. Innovations in terms of value for the clients in the sector of transportation services of cargo tranport

(Source: Antonowicz 2014)

Identification of the service value from the client perspective may also provide the foundation to introduce market segmentation. On the basis of which there is a possibility of process personalization and classification of clients in terms of price sensitivity and positioning offers of transportation services. The innovative solution can be based, for example, on the process of services value creation with the participation of customers what is connected with so called prosuments approach.

The subsequent group of transportation services price determinants covers factors related to market. The rate of transportation services prices shall be adjusted to current market needs. The important role here is played by the price elasticity demand, the knowledge of which allows to forecast the reaction of the demand on the prices change. In case of extensive price elasticity demand, the manufacturer of transportation services shall not raise the price for offered services. It could lead to the decrease of the demand for cargo transportation and result in the decrease of company's income. Whereas, low value of a mentioned indicator could be considered as prerequisite of price raise.

The prices rate of transportation services shall also depend on the number of business entities offering the same type of services - number of companies with similar competitive position and market share. Price policy shall take into consideration the results of benchmarking, that means it shall be based on the results of the comparative analysis of the prices height and pricing strategy set by competition. Moreover, also the identification of the 
perception of the quality of the transportation services by the clients, compared to competition, seems to be of crucial importance. It is suggested to create, so called, services perception maps which reflect means of perception by the clients of a particular company and competition operating on the same market sector (Czubała et al. 2006). The maps may constitute the basis of the enterprise price policy.

Moreover, according to Bondos (2015) companies should strive to reduce the consumers price sensitivity by identifying elements of their offer, that are significantly distinguish it from the proposals of market competitors. In other words, the attention of consumers should be focused on the value of the services provided that are characteristic for particular transportation company (Bertini, Wathieu 2010). Thanks to such approach the enterprises would be able to stand out on the market, gain profits and develop dynamically.

\section{Conclusions}

In the modern reality, most of the enterprises used the profitability growth potential coming from traditional costs optimization. Contrary, the majority of costs constantly raise and the companies frequently lose the possibility to base their business models on low costs base. The starting point from such a situation seems to be correct pricing strategy. Pricing strategy should be one of the most important key to the success of each business. According to Piercy et al. "pricing should move from being a simple tactical tool into being a strategic tool" (Piercy et al. 2010). It could change customer's behaviour as well as bring new market opportunities, so it should be treated as powerful tool to improve customers satisfaction and company's profitability.

Establishing of optimal level and price structure does not seem to be an easy task. However, innovation in pricing may be a company's most but also in many cases least explored source of competitive advantage (Hinterhuber, Liozu 2014).

The process of constructing the optimal pricing strategy requires, inter alia, a team of qualified experts who will be analysing the current market situation (Hawlena 2011).

In authors opinion, one of the most important stages, the starting point in the pricing strategy setting process is the identification of the determinants of transport services price. In the article, five groups of the determinants of transport services price were introduced. According to the research results, the main price determinants should be re- lated to the prime costs, the basis costs of transportation enterprise functioning, the customer needs, the market and the competition analysis. In addition, the reference solution would be to develop a pricing strategy with precisely defined pricing model, which should integrate three types of price policies: oriented on costs, oriented on competition and oriented on demand.

The transportation enterprise should also develop the segmentation and positioning strategy and use it in the process of construction of pricing model. It would be the remarkably innovative approach in the pricing in railway cargo transport, especially in Poland. The results of the conducted analysis show that currently in Poland, rail operators use the "cost plus" pricing model. Price of the transport service is based on unit costs and price margins and ignores external relations for example the influence of consumers and competition of prices.

In the pricing policy, the system of monitoring of pricing strategy is also very important. It should be based on the analysis of so-called break-even point (BEP) and the analisis of the dependence between quantity and price, as well as between price and the length of the route. Moreover, the enterprise should elaborate the recommendations for carrying out changes in the company's image and base provided services creation on the value perceived by clients.

In the future, the authors are planning to develop dynamic pricing model dedicated to railway transport, which will shape the prices in real time. It will be differentiating prices according to presented determinants of prices.

\section{References}

Antonowicz, M. 2014. Innowacje marketingowe $\mathrm{w}$ przedsiębiorstwie [Marketing innovations in the enterprise], Transport i Komunikacja 2: 42-44 (in Polish).

Bertini, M.; Wathieu, L. 2010. How to stop customers from fixating on price?, Harvard Business Review 88(5): 84-91.

Bondos, I. 2015. Postrzeganie atrakcyjności cenowej pakietu usług [Perception of service bundle price attractiveness], Logistyka 2: 1394-1399 (in Polish).

Bronk, H. 2015. Cechy i układ kosztów w transporcie umożliwiające podejmowanie decyzji [Characteristics and arrangement of costs in transport, enabling decision-making], Uniwersytet Szczecinski Zeszyty Naukowe 813 Problemy Transportu i Logistyki 25: 21-40 (in Polish). 
Czubała, A.; Jonas, A.; Smoleń, T.; Wiktor, J. W. 2006. Marketing ustug [Services marketing]. Wolters Kluwer Polska Sp. z o.o (in Polish).

DB Schenker Rail Polska freight tariff. 2016 [online], [cited 12 January 2016]. Available from Internet: https://www.rail.dbschenker.pl/file/rail-polska1/7546492/OtQBMiDgpyNFgWSOP22qEp5YkaY/ 8970504/data/taryfa_towarowa_marzec.pdf

Dyhdalewicz, A. 2011. Wybór metod ustalania cen w przedsiębiorstwach handlowych [The choice of pricing methods in commercial enterprises], Zeszyty Naukowe Uniwersytetu Szczecińskiego 625, Finanse, Rynki Finansowe, Ubezpieczenia 32: 127140 (in Polish).

Freight tariff of CTL Logistics. 2016 [online], [cited 23 January 2016]. Available from Internet: http://www.ctl.pl/Media/download/15/tt2.pdf

Simon-Kucher \& Partners. 2014. Global pricing study [online], [cited 02 March 2016]. Available from Internet: http://www.simon-kucher.com/en-us/content/pricing

Hawlena, J. 2011. Strategia ceny wysokiej czy strategia ceny niskiej? Analiza wariantów współczesnych strategii cenowych w branśy lotniczej [High price strategy or low price strategy? An analysis of options of modern prices pricing strategies in airline industry], Logistyka 3: 857-866 (in Polish).

Hinterhuber, A. 2008. Value delivery and value-based pricing in industrial markets, Advances in Business Marketing and Purchasing 14(8): 381-448.

Hinterhuber, A.; Liozu, S. M. 2014. Is innovation in pricing your next source of competitive advantage?, Business Horizons 57(3): 413-423. http://dx.doi.org/10.1016/j.bushor.2014.01.002

Iveroth, E.; Westelius, A.; Petri, C.-J.; Olve, N.-G.; Cöster, M.; Nilsson, F. 2013. How to differentiate by price: proposal for a five-dimensional model, European Management Journal 31(2): 109-123. http://dx.doi.org/10.1016/j.emj.2012.06.007

Jaruga, A. A.; Nowak, W. A.; Szychta, A. 1999. Rachunkowość zarzqdcza. Koncepcje i zastosowania [Managerial accounting. Concepts and applications]. Społeczna Wyższa Szkoła Przedsiębiorczości i Zarządzania w Łodzi (in Polish).

Kotler, P. 1999. Marketing. Analiza, planowanie, wdrażanie i kontrola [Marketing Management. Analysis, planning, implementation, and control]. FELBERG (in Polish).
Koźlak, A. 2007. Ekonomika transportu. Teoria i praktyka gospodarcza [Transport economics. Economical theory and practice]. Wydawnictwo Uniwersytetu Gdańskiego (in Polish).

Nagle, T. T.; Hogan, J. E.; Zale, J. 2011. The strategy and tactics of pricing. A guide to growing more profitably. Pearson Education.

Piercy, N.; Cravens, D.; Lane, N. 2010. Thinking strategically about pricing decisions, Journal of Business Strategy 31(5): 38-48. http://dx.doi.org/10.1108/02756661011076309

Rokicki, T. 2014. Organizacja i ekonomika transportu [Transport and economy organization]. Wydawnictwo SGGW (in Polish).

Shipley, D.; Jobber, D. 2001. Integrative pricing via the pricing wheel, Industrial Marketing Manageement 30: 301-314. http://dx.doi.org/10.1016/s0019-8501(99)00098-x

Sokołowska, E.; Schulz, M. 2014. Metody ustania cen produktów na rynku usług w Polsce, Prace Naukowe Uniwersytetu Ekonomicznego we Wroclawiu 353: 155-164.

Tariff of railway Transport of Lotos Kolej. 2016 [online], [cited 23 January 2016]. Available from Internet: http://www.lotos.pl/1232/grupa kapitalowa/ nasze_spolki/lotos_kolej/regulamin_przewozow _towarowych_/taryfa_uslug_kolejowych

Terms and conditions of cargo transport services by PKP Cargo. 2016 [online], [cited 02 February 2016]. Available from Internet:

http://www.pkpcargo.com/en/customer-zone/tariffs -and-documents/

Töytäri, P.; Rajala, R.; Alejandro, T. B. 2015. Organizational and institutional barriers to value-based pricing in industrial relationships, Industrial Marketing Management 47: 53-64.

http://dx.doi.org/10.1016/j.indmarman.2015.02.005

Urbany, J. 2000. Pricing strategies and determination. Marketing. Best practices. Orlando: The Dryden Press.

Waniowski, P. 2014. Marketingowe zarzadzanie cena $w$ przedsiębiorstwie [Market price management in the enterprise]. Wydawnictwo Uniwersytetu Ekonomicznego we Wrocławiu (in Polish).

Website of the Office of Rail Transport in Poland. 2016 [online], [cited 02 March 2016]. Available from Internet: http://www.utk.gov.pl 